\title{
El pintor Juan de Peñalosa y Sandoval, de Córdoba a Astorga
}

\author{
María MeLERO LEAL
}

Universidad de Córdoba

\begin{abstract}
RESUMEN. Este trabajo pretende ser un estudio abreviado, pero global, de la vida y obra del pintor Juan de Peñalosa en el que documentaremos aspectos de su biografía que hasta ahora eran desconocidos, y puesto que mucho de lo publicado sobre nuestro pintor está basado en fuentes no contrastadas, rectificaremos algunos datos, abriendo nuevas vías de investigación. También revisaremos el catálogo de su producción artística añadiendo algunas obras que se extienden más allá del ejercicio de la pintura y que perfilan la biografía de un polifacético artista erudito del Renacimiento, entendido al modo italiano siguiendo las huellas de su maestro Pablo de Céspedes.

Palabras clave: Pintura, Astorga, Córdoba, Siglo XVII, Retablo.

Abstract. This paper aims to be a brief but comprehensive study on painter Juan de Peñalosa's life and work. We will comment on aspects of his life which remained unknown so far. Due to the fact that the majority of the work on this painter is based on non-contrasted sources, we will correct some of the existing information and we will open new ways of research. We will review the corpus of his artistic production as well by adding some works that go beyond the field of painting and can highlight the biography of this versatile, learned artist. A Renaissance artist in the Italian style who followed the example of his teacher: Pablo de Céspedes.

Key words: Painting, Astorga, Córdoba, 17th Century, Altarpiece.
\end{abstract}

Juan de Peñalosa y Sandoval fue, según la tradición historiográfica, el más cercano seguidor del conocido humanista, artista y racionero cordobés Pablo de Céspedes ${ }^{1}$. Sabemos que vivieron bajo un

\footnotetext{
${ }^{1}$ Pintor, escritor, teórico, poeta, arquitecto, escultor y racionero de la catedral de Córdoba. Todas las fuentes coinciden en que Juan de Peñalosa fue uno de los más cercanos seguidores de Céspedes, dato que queda confirmado en la documentación. Vid.: F. PACHECO, Libro de descripción de verdaderos Retratos de Ilustres y Memorables varones, 1599, Sevilla 1985, pp. 99104; F. M. Tubino, Pablo de Céspedes, Madrid 1868; J.
}

BROWN, «La teoría del arte de Pablo de Céspedes», Revista de Ideas Estéticas, no 90, 1965, pp. 95-105; M. A. RAYA RAYA, Catálogo de las Pinturas de la Catedral de Córdoba, Córdoba 1988; F. M. Quílez CORELLA, «La cultura artística de Pablo de Céspedes», Boletín del Museo e Instituto 'Camón Aznar', no 39, 1990, pp. 65-85; J. Rubio LAPAZ, Pablo de Céspedes y su círculo. Humanismo y Contrarreforma en la cultura andaluza del Renacimiento al Barroco, Granada 1993; M. PÉREZ LOZANO, El Gongorismo y el Culteranismo en la Pintura andaluza del siglo de Oro, tesis doctoral inédita, Córdoba 1993. P. DÍAZ CAYEROS «Pablo de Céspedes entre Italia y España», Anales del Instituto de Investigaciones Estéticas, $\mathrm{n}^{\mathbf{0}}$ 76, 2000, pp. 5-60. 
mismo techo gracias al poder para testar que Céspedes otorgó a favor del canónigo Álvaro Piçaño de Palacios el día de su muerte, ocurrida el 26 de julio de $1608^{2}$ : “...y a Juan de Peñalosa asimismo que tengo en mi casa treynta ducados y sus vestidos" ${ }^{\prime 3}$. Siendo ya difunto el racionero, se realizó el inventario de los bienes que poseía, y en este documento, se menciona lo siguiente: ...estando presentes Andres Ruiz y Juan de Peñalosa que an residido en las dichas casas en servicio del dicho Pablo de Cespedes... ${ }^{4}$. Este dato nos permite ir un poco más allá y asegurar que Peñalosa estaba al servicio de Céspedes, muy probablemente en condición de criado, pero a la vez, haciendo las veces de aprendiz del maestro, como se desprende por la clara herencia cespediana de la pintura, poesía y estilo de vida del segundo.

Tradicionalmente se ha mantenido la versión de Palomino que dató el nacimiento de Peñalosa en Baena entre 1581 y 1582 y la muerte en Córdoba a los 54 años en $1636^{5}$. Dado que hoy sabemos que erró en el lugar y fecha de defunción, pues existe el testimonio del fallecimiento del pintor en un protocolo notarial de Astorga conservado en el Archivo Histórico Provincial de León, y que sitúa fehacientemente el óbito el 31 de mayo de 1633, pensamos que el lugar y fecha de nacimiento también podrían someterse a juicio ${ }^{6}$.

${ }^{2}$ F. PACHECO, op. cit., pp. 99-104.

${ }^{3}$ Archivo Histórico de Protocolos de Córdoba (AHPCO), protocolos de Córdoba, of. 22, tomo 71, notario Alonso Rodríguez de la Cruz. 1608, 26 de julio, sin foliar.

${ }^{4}$ Ibídem, 26 de julio, 28 de julio y 24 de agosto, sin foliar.

${ }^{5}$ A. A. Palomino y Velasco, Vidas, 1724, Madrid 1986, p. 111.

${ }^{6}$ CONDE DE LA VIÑAZA, Adiciones al diccionario histórico de los más ilustres profesores de bellas artes en España de Agustín Ceán Bermúdez, Tomo III. Madrid, 1984, p. 225. Ya a finales del XIX apuntó la marcha a Astorga para trabajar al servicio de Messía de Tovar y
Siguiendo a Palomino, Ceán Bermúdez $^{7}$ y Rafael Ramírez de Arellano ${ }^{8}$ fijaron el año de su nacimiento en 1581, siendo aceptada esta cronología hasta que Valverde Perales publicó, en 1903, una supuesta partida de bautismo de Juan de Peñalosa. Según este documento, que ha venido aceptándose por la historiografía más reciente, el pintor fue hijo de Francisco de Peñalosa y Ana Ximenez siendo bautizado en la Parroquia de San Bartolomé de Baena el 7 de noviembre de $1579^{9}$.

De acuerdo con la documentación que hemos consultado y que actualmente se conserva en el Archivo Histórico Provincial de Córdoba, en la sección de Protocolos Notariales de Baena, la partida de bautismo publicada por Valverde, que hoy está desaparecida porque los archivos de la Parroquia de San Bartolomé de Baena fueron destruidos durante el último periodo republicano, no parece corresponder al Juan de Peñalosa objeto de nuestro estudio sino a un homónimo que probablemente muriera en una fecha anterior a $1622^{10}$. Esta afirma-

la muerte en esta ciudad en 1636, aunque solamente este dato fue seguido y corroborado por Llamazares Rodríguez que publicó el testamento, inventario de bienes y almoneda. F. LLAMAZARES RODRÍGUEZ, «Juan de Peñalosa y Sandoval. Enfermedad, testamento, muerte y almoneda» en Tierras de León, 41, León, 1980. Pese a estas publicaciones, muchos historiadores no han tenido en cuenta esta documentación y han seguido situando la muerte del pintor en Córdoba y negando su marcha a Astorga.

${ }^{7}$ J. A. CEÁn BeRmúdeZ, Diccionario Histórico de los más Ilustres Profesores de las Bellas Artes de España, Madrid, 1800, Tomo 6, p. 82.

${ }^{8}$ R. RAMÍREZ DE ARELlANO y DÍAZ DE MORALES, Ensayo de un catálogo biográfico de escritores de la provincia y diócesis de Córdoba con descripción de sus obras, Madrid, 1922, p. 470.

${ }^{9}$ F. VALVERde Perales, Historia de la Villa de Baena, Toledo, 1903, p. 384.

${ }^{10}$ M. MELERO LEAL, «Un ejemplo de ascenso social a través de la pintura. Juan de Peñalosa y Sandoval» en Congreso Internacional Las Élites en la Época Moderna: la Monarquía Española, Córdoba, 25-27 de octubre de 2006 (en prensa). 
ción se sustenta en el hecho de que no aparece nombrado como hijo en el testamento de la que fue la única esposa del único Francisco de Peñalosa registrado en Baena en la época, llamada Ana Fernández (y no Ana Ximénez, tal y como publicó Valverde, debiéndose este error, muy posiblemente, a una lectura equivocada de las abreviaturas que se usaban en el siglo XVII de ambos apellidos), siendo esto extraño, máxime si tenemos en cuenta que sí aparecen mencionadas en él, las hijas vivas que tuvo la pare$\mathrm{ja}^{11}$.

El primer dato seguro de la vida del pintor es que residió en casa de Pablo de Céspedes, información que, además de lo manifestado por Céspedes en el poder para testar, queda corroborada en los Padrones Sacramentales que se encuentran en el Archivo de la actual Parroquia del Sagrario de la Catedral de Córdoba, antes Parroquia de Santa María o Parroquia de la Iglesia Mayor, o Santa Iglesia, donde en la relación de las personas que vivían en la casa de Céspedes en la Calleja de Ramírez ${ }^{12}$ en 1609, un año después de la muerte del racionero, aparece Juan de Peñalosa. No tenemos datos de años anteriores porque las páginas referentes a la casa de Pablo de Céspedes, han sido cortadas del correspondiente tomo ${ }^{13}$.

Según estos padrones, a la muerte de Céspedes, Peñalosa vivía en esta casa con sus familiares Alonso de Peñalosa y María Magdalena, su mujer. Del platero Alonso de Peñalosa, hasta la fecha sólo tenemos

\footnotetext{
${ }^{11}$ AHPCO. Protocolos de Baena, Of. 3b, (Pedro de Comarcada), año, 1620, fol. 415-420.

${ }^{12}$ Esta calleja es denominada de varias formas en los padrones: Calleja de Ramírez, Calleja de Ortuño, Calleja de Peñaranda, aunque el nombre más veces usado es el primero que señalamos.

${ }^{13}$ Archivo de la Parroquia del Sagrario de Córdoba. Sección de Padrones Sacramentales. Padrones de la Collación de Santa María de los años 1606-1619. Año 1609. Sin foliar.
}

dos referencias, una partida de bautismo en la Parroquia del Sagrario de Córdoba, el 1 de septiembre de 1555, siendo sus padres Alonso de Palma y María de Peñalosa ${ }^{14}$ y el hecho de que firmase en el poder para testar de Céspedes que antes mencionamos. Este último dato es una prueba de que el platero fue una persona cercana al círculo de Céspedes, ya que estuvo presente en su lecho de muerte.

Por el orden en que estos tres personajes aparecen mencionados en la relación de habitantes de esta casa, y si tomamos como referencia cómo se solía enumerar en la época las familias en los padrones (cabeza de familia, esposa, hijos y personas dependientes) podríamos pensar que Alonso de Peñalosa y su esposa fueron los padres de nuestro pintor, aunque no tenemos, hasta la fecha, ningún documento que lo demuestre, y sólo nos podemos apoyar en estos datos y en el hecho de que Alonso sería excesivamente mayor para ser hermano del pintor.

Tampoco tenemos más documentación que aclare las incógnitas sobre la vida del pintor en Córdoba, salvo su presencia en la ciudad por las obras firmadas y fechadas entre 1609 y 1613 y por su participación en dos eventos literarios entre 1614 y $1617^{15}$.

-

${ }^{14}$ Archivo de la Parroquia del Sagrario de Córdoba. Libro de Bautismos 1, Parte Tercera, fol. 176. Actualmente estamos continuando la investigación en Archivos sobre este personaje para así poder determinar si, como hipotéticamente suponemos, efectivamente, éste era el padre de Juan de Peñalosa, pues tal y como aparecen reseñados los nombres en el Padrón y por las fechas, bien podrían ser padre e hijo.

${ }^{15}$ R. RAMíreZ De ARELLANO en su Ensayo de un catálogo biográfico de escritores de la provincia y diócesis de Córdoba con descripción de sus obras, dice que en 1614, Peñalosa participó en una certamen poético celebrado en el Convento de Santa Ana de Córdoba, en el que obtuvo el tercer premio junto con Enrique Brito. Más adelante, también señala su participación en la justa literaria celebrada en la Parroquia de San Andrés en 
Es plausible que en estos momentos estuviese realizando estudios eclesiásticos si no los tenía acabados, ya que en los textos de poesía conservados a raíz de sendos certámenes literarios va a recibir el tratamiento de Don, algo que en la época normalmente iba dirigido a quienes poseían o realizaban estudios superiores.

Otro dato curioso es que en todas las referencias al pintor halladas en Córdoba, éste se hace llamar Juan de Peñalosa, no adquiriendo el segundo apellido "de Sandoval" hasta su llegada a Astorga. Rafael Ruiz Arjona dice que el pintor tomó este segundo apellido del que pudiera ser su abuelo y apunta que el pintor podría estar relacionado con Francisco Bravo de la Rosa $\mathrm{y} \mathrm{Sandoval}^{16}$, un personaje que fue regidor de Martos (provincia de Jaén), Familiar del Santo Oficio en Lucena y natural de Baena, en el siglo XVIII ${ }^{17}$. Nosotros creemos que relacionar a Peñalosa con la casa solar de Almedina de Baena sin más datos que los de una persona que vivió en el siglo XVIII y que compartía el segundo apellido con Juan de Peñalosa, es algo que no está lo suficientemente fundamentado y que debe ser rechazado si no existe más documentación que lo demuestre.

No sabemos realmente de dónde tomaría este apellido ni la razón de por qué empieza a usarlo sólo a partir de su llegada a Astorga, pero sí podemos apuntar que según la documentación hallada en el Archivo Provincial de León, no solamente fue el pintor quien usó el segundo apellido de Sandoval, si no también su único familiar seguro conocido, su hermano Gaspar ${ }^{18}$.

\footnotetext{
1617.

${ }^{16}$ R. RUíz ARJONA, «Juan de Peñalosa y Sandoval», Revista Tambor, no 11, Baena, 2000, p. 10.

${ }^{17}$ J. A. MARTínez BARA, Catálogo de informaciones genealógicas de la Inquisición de Córdoba conservadas en el Archivo Histórico Nacional, Madrid, 1970.

${ }^{18}$ Archivo Histórico Provincial de León (AHPL).
}

Hasta que el Conde de la Viñaza apuntara su marcha y muerte en Astorga y descubriera que en esta ciudad asumió este segundo apellido, ningún historiador había recogido el nombre completo que usaba en esta ciudad, siendo solamente seguido por Ramírez de Arellano ${ }^{19}$ y la historiografía que, acertadamente, relacionó al Juan de Peñalosa cordobés con el que vivió en Astorga.

La escasa disponibilidad de documentación nos impide llegar a saber la causa de su marcha a Astorga, aunque sí nos atrevemos a señalar que ésta se produjo de una manera planeada, y que Peñalosa podría estar en relación con algún personaje cercano a Alonso Messía de Tovar. Esto no es algo extraño si tenemos en cuenta que, el hermano del prelado, Pedro Messia de Tovar, fue caballero de Santiago, Vizconde de Tovar, Conde de Molina de Herrera, y Señor de ciudades muy relacionadas con Céspedes y todo el círculo literario y pictórico que le rodeaba, como Antequera o Córdoba.

Con su traslado, Juan de Peñalosa llega a una de las diócesis más grandes, antiguas y ricas de toda la Península Ibérica en el siglo XVII, contando con alrededor de 900 parroquias, una veintena de arciprestazgos y con una Catedral Gótica cuyas obras habían comenzado en 1471 y que en el siglo XVII se culminaron en su interior, quedando pendiente la fachada (que no se realizaría hasta el siglo XVIII) y la dotación decorativa interior, empresa muy suculenta para cualquier pintor ${ }^{20}$.

Protocolos de Astorga, Oficio de Felipe Becerra, año 1632, caja 9949, fol. 1191-1192.

${ }^{19}$ CONDE DE LA VIÑAZA, Adiciones al diccionario... Op. Cit., p. 225. y R. RAMírez de ARELLANO y DíaZ DE MORALES, Ensayo de un catálogo... Op. Cit., p. 470.

${ }^{20}$ Vid. M. RODRíGUEZ DíEZ, Historia de la muy noble, real y benemérita ciudad de Astorga, Madrid, 1981. 
En 1616 había sido nombrado obispo de la diócesis asturicense Alonso Messía de Tovar, personaje profundamente piadoso y culto tal y como se demuestra en De Vera et Falsa Gloria $^{21}$. Es muy probable que, siguiendo con el esquema de personaje humanista y culto, relacionado con el mundo artístico y poético que quería imitar modelos italianos, reclamase obras inspiradas en los preceptos de Trento, y en los círculos artísticos cultos andaluces, donde Juan de Peñalosa encajaría a la perfección, como discípulo directo y más cercano de Céspedes, ejemplo a seguir del "hombre del renacimiento" por sus habilidades en la pintura, el diseño de arquitectura, la poesía, etc.

Así, el nuevo pintor, se encargaría de llevar a cabo, para la Catedral, obras en relación con una pintura culta, cargada de simbología religiosa, alejada de lo puramente gremial y más relacionada con conceptos metafísicos y en muchas ocasiones herméticos ${ }^{22}$. No podemos dejar de aclarar, llegados a este punto, que este tipo de pintura estaba ya algo pasada de moda en la segunda década del setecientos, y quizá fuese este el motivo de que Peñalosa recibiera pocos encargos para la catedral de Córdoba, en la que por las fechas se estaban ornamentando las Capillas y tuviese que buscar encargos en otros lugares o aceptase de buen grado los llegados de tierras lejanas.

${ }^{21}$ A. Messía DE TOVAr, De Vera et Falsa Gloria, Imprenta de Jerónimo Murillo, Astorga, 1624.

${ }^{22}$ Para conocer los conceptos pictóricos de Céspedes: F. M. Quílez CORELlA, «La cultura artística de Pablo de Céspedes», Boletín del Museo e Instituto 'Camón Aznar', no 39, 1990, pp. 65-85; J. RuBio LAPAZ, Pablo de Céspedes y su círculo. Humanismo y Contrarreforma en la cultura andaluza del Renacimiento al Barroco, Granada, 1993; M. PÉREZ LOZANO, Conceptismo y Culteranismo en la Pintura Andaluza del Siglo de Oro. Universidad de Córdoba 1993. Tesis Doctoral inédita.
Un factor a tener en cuenta en este punto es que tanto en Astorga, como en el ámbito de la diócesis, no abundaban los pintores. Conocemos a un pintor que vivió en Astorga hasta, aproximadamente, 1622 ó 1623. Este pintor es Juan de Ulierte, que era vecino de Astorga pero natural de "Bizkaia" (sic), y que en 1622 no estaba en condiciones de pintar como declara en su testamento, otorgado en ese mismo año ${ }^{23}$. No hemos encontrado más documentación referente a este pintor, por lo que podríamos pensar que su muerte ocurrió poco tiempo después de la redacción del testamento. Seguramente, alguno de sus hijos se dedicara a la pintura, ya que en un documento de 1632, aparece mencionado como testigo, Pedro de Ulierte, pintor ${ }^{24}$.

Además de Ulierte, también hemos encontrado referencias a otro pintor vecino de Astorga, Gabriel Martínez, quien es probable recibiera menos encargos o de menor calidad a juzgar por la escasez de datos protocolizados $^{25}$.

Lo curioso en este caso es que, mientras que existen numerosas referencias a obras realizadas por maestros escultores y ensambladores, como Lupercio Getino, Gregorio Español, Francisco Ruíz, Amaro Pérez, etc., que van a trabajar para la Catedral y para otras iglesias de la diócesis, no ocurre igual con las obras pictóricas, que aunque escasas, se realizaron en el momen$\mathrm{to}^{26}$.

\footnotetext{
23 AHPL. Protocolos de Astorga, Oficio de Luis Gaspar, año 1622, caja 9479, fols. 603-620.

${ }^{24}$ AHPL. Protocolos de Astorga, Oficio de Felipe Becerra, año 1632, caja 9499, fol. 558.

25 Sólo hemos hallado un par de referencias a este

AHPL. Protocolos de Astorga, Oficio de Pedro de Salazar, año 1627, caja 9417, fol. 1365.

AHPL. Protocolos de Astorga, Oficio de Bartolomé Rodríguez, año 1631, caja 9454, fol. 634.

${ }^{26}$ Algunos de estos documentos fueron publicados por: F. LlAMAZARES RODRÍGUEZ, El retablo Barroco
} pintor: 
Por la trayectoria artística de Peñalosa, la documentación hallada (entre la que no hemos encontrado ningún documento referente a la realización de sus obras) y lo que sabemos de Céspedes se puede deducir que éste, al igual que el racionero, tenía por costumbre no aceptar encargos remunerados de pintura como solían hacer los pintores, que en la época, hacían de la pintura su medio de vida y esto era porque para ellos, este tipo de actividades, podrían relacionar a la pintura con una actividad más gremial que cultural, siendo éstos, unos conceptos que no encajaban con la idea que tenían de la pintura. Ambos artistas sostenían su economía en sus cargos y prebendas eclesiásticas (Céspedes en la ración y Peñalosa en el canonicato, como más adelante trataremos) alejándose del resto de pintores que realizaban encargos de pintura por dinero, situándose en estos casos la pintura cercana a los oficios manuales.

Sabemos con seguridad que el pintor estaba en Astorga en 1621, ya que existe un documento en el que Peñalosa se obliga a pagar 80 reales a Miguel López Caballos, mercader, por cinco varas de paño ${ }^{27}$. A partir de este momento, empieza a tomar importancia en la diócesis recibiendo diferentes cargos eclesiásticos, por lo que sería de esperar que, aunque no hemos hallado documentación al respecto, se recibiese de sacerdote en Córdoba, poco tiempo antes de trasladarse o justo al llegar a Astorga, siendo esto último lo que nos parece más acertado.

Que se ordenase en Astorga es una hipótesis que podría estar reforzada por el hecho de que en este documento de 1621, Peñalosa dice ser vecino de dicha ciudad,

en la provincia de León, León, 1991.

27 AHPL. Protocolos de Astorga, Oficio de Luís Gaspar, año 1621, caja 9478, fol. 485. Agradecemos las referencias documentadas facilitadas por D. Manuel Pérez Lozano y D. Antonio Urquízar Herrera. pero no menciona ninguna actividad profesional como solía hacerse en la época, es decir, no dice ser pintor o clérigo. Este es el único documento que tenemos en que no indique su estatus en la carrera eclesiástica, lo que nos hace pensar que quizá por estas fechas, no hubiese recibido aún ningún puesto en el cabildo catedralicio de la ciudad y que el pintor, estuviese todavía recién llegado.

En el caso de haber sido ordenado sacerdote por el propio Obispo Messía de Tovar, podría aquí verse una clara estrategia para introducirle en el cabildo, ofrecerle prebendas que terminasen para siempre con sus problemas económicos ${ }^{28}$ y que a cambio, Peñalosa actuará, como su asesor artístico, algo que además encajaría perfectamente con las ideas que el pintor había heredado de Céspedes, de no llevar a cabo contratos de pintura y vivir de los beneficios provenientes de su cargo eclesiástico. Las obras que realizó finalmente, están cargadas de religiosidad y rebosantes de conceptos relacionados con la poesía y los ideales, tanto religiosos como políticos del prelado, todo ello propiciado por las peticiones del mismo y tamizado por el carácter del pintor.

Todos los documentos que hemos podido consultar de Peñalosa durante su estancia en Astorga nos han llevado a descubrir un sistema de pago totalmente diferente al que era usual en la época. No hemos hallado los documentos referentes a las pinturas que realizó, y además, es casi seguro que éstos no existan y esto es porque al igual que Céspedes, no realizó con-

28 Según algunos documentos hallados en el AHPL, en sus primeros años en Astorga, el pintor podría haber tenido problemas económicos tal y como se desprende del hecho de existir algún documento de retraso y aplazamiento de pagos debidos: AHPL. Protocolos de Astorga, Oficio de Luís Gaspar, año 1621, caja 9478, fol. 485. 
tratos de pintura ni en Córdoba ni en Astorga.. No obstante, actuó en el contrato de diseño dorado y pintura del retablo de la Inmaculada de la Catedral de Astorga, que como sabemos él diseñó y dotó con las pinturas que aún hoy lo decoran. Esto puede deberse a que la actividad de diseñar, como trabajo mental, podría ser vista de una manera muy diferente a la realización manual de pinturas ${ }^{29}$. Así vemos cómo Peñalosa sí ejerció la labor de asesor, fijando las condiciones de las obras, pero nunca como parte contratante ni recibiendo remuneración por ello.

En un estudio sobre el ascenso social del pintor en la diócesis, apuntábamos lo curioso de éste, que se podría calificar de inmediato y rápido. Inmediato porque en 1622, muy poco tiempo después de su llegada, ya dice ser clérigo presbítero y familiar ${ }^{30}$ de su señoría el Señor Obispo ${ }^{31}$ y rápido, porque a partir de este momento, el pintor fue ascendiendo en la diócesis, siendo nombrado canónigo en 1624 hasta llegar, en 1632 a vicedeán, coincidiendo todos sus ascensos, con la elaboración de importantes obras para la Catedral asturicense.

El primer documento donde se nos revela el que creemos, fue su primer paso en la carrera eclesiástica, es del 17 de marzo de este mismo año de 1622 por el que realiza un arrendamiento de las tierras asociadas a una Capilla de la que había sido nombrado Capellán y que se encontraba en

\footnotetext{
${ }^{29}$ AHPL. Protocolos de Astorga, Oficio de Pedro Salazar, año 1627, caja 9417, fol. 45-50. Este documento ya había sido publicado por F. LLAMAZARES RODRÍGUEZ, El retablo... Op. Cit, p. 174.

${ }^{30}$ Debemos entender familiar como eclesiástico o paje dependiente y comensal de un obispo, según el Diccionario de la Real Academia Española.

31 AHPL. Protocolos de Astorga, Oficio de Luís Gaspar, Año 1622, Caja 9479, fol. 331.
}

una localidad de Morales del Rey (actual provincia de Zamora) $)^{32}$.

No hemos hallado documentación referente al año 1623, lo que pudiera hacer pensar en un traslado o estancia en otra ciudad, de la que habría vuelto en 1624, año en que el pintor recibió una Canonjía según un documento donde se menciona a Juan de Peñalosa como canónigo y prestamero del préstamo ${ }^{33}$ de la Catedral en octubre de $1624^{34}$. A este respecto, ya Pérez Lozano apuntó una posible estancia en Córdoba del pintor en esta fecha, gracias a las anotaciones manuscritas en un libro de las Metamorfosis de Ovidio que se encuentra en la Biblioteca Municipal de esta ciudad, que fue publicado en 1622 en cuya portada puede leerse: Soi de D. Juan de Peña/losa ${ }^{35}$.

Analizando los documentos referentes al Cabildo Catedralicio asturicense, se puede observar su ascenso dentro de éste. A partir de 1625, el nombre de Don Juan de Peñalosa y Sandoval irá apareciendo en los últimos lugares de la lista, para posteriormente, ir subiendo de posición hasta aparecer el primero en 1632, momento en que estaba ejerciendo el oficio de Vicedeán de la Catedral $^{36}$. Así llegó a ocupar puestos más

-

${ }^{32}$ Idem, fol. 288-289.

${ }^{33}$ Según el Diccionario de la Real Academia, un prestamero, es el eclesiástico que posee una prestame$\mathrm{ra}$, que es un estipendio o pensión procedente de rentas eclesiásticas que se daba temporalmente a los que estudiaban para sacerdotes o a los que militaban por la Iglesia, y que después se convirtió en una especie de beneficio eclesiástico.

${ }^{34}$ AHPL. Protocolos de Astorga, Oficio de Pedro Salazar, Año 1624, Caja 9414, fol. 644-645.

${ }^{35}$ OVIDIO, Las metamorphoses, o transformaciones del excelente Poeta Ovidio, en quinze libros buelto en Castellano. Aora nuevamente Corregidas en esta impresion. Con licencia. En Madrid, por la viuda de Alonso Martin. Año MDCXXII.

${ }^{36}$ AHPL. Protocolos de Astorga, Oficio de Pedro Salazar, año 1625 , caja 9415 , fol. 747-749; año 1625, caja 9415, fol. 806; año 1626, caja 9416, fol. 170-171; año 1627, caja 9416, fol.45 y Oficio de Francisco Balboa, año 1632, caja 9530, fol. 946-94. 
relevantes en la jerarquía eclesiástica que los logrados por el propio Céspedes, su maestro, ya que al ser canónigo y, posteriormente Vicedeán, tenía acceso a un canonicato mejor prebendado.

Los beneficios que obtenía de las tierras, censos, arrendamientos y el canonicato, los usaba para negociar, realizando gran cantidad de préstamos, tanto monetarios como fructuarios, y arrendamientos que le hicieron prosperar económicamente, y que se fueron haciendo cada vez más abundantes a partir de $1628^{37}$. Pese a esto, debido a los pleitos y préstamos que llevó a cabo, al final de su vida, todos sus ahorros no daban más que para subsanar el pago de las deudas contraídas en sus últimos años ${ }^{38}$.

A partir de 1631 Juan de Peñalosa va adquiriendo cada vez más seguridad económica y estabilidad en el Cabildo. Esto seguramente hizo que pudiera llegar a un trato con el Cabildo de la Catedral que le arrendó, de por vida, la casa en la que vivió hasta su muerte que disponía de varias habitaciones para el canónigo y sus cria$\operatorname{dos}^{39}$.

En 1632 la vida de Peñalosa dio un cambio debido a que empezó a desempeñar el oficio de Vicedeán de la diócesis de Astorga $^{40}$. Ocupó el cargo hasta un momento

\footnotetext{
${ }^{37}$ Algunos de los documentos de préstamos, censos y arrendamientos son:

AHPL. Protocolos de Astorga, Oficio de Pedro Salazar, año 1624, caja 9414, fol. 644-64; año 1626, caja 9416, fol. 390; año 1627, caja 9416, fol. 391 y 680-681; año 1630 , caja 9419 , fol. 4-5, 175-176, 379-381 y 690-691.

AHPL. Protocolos de Astorga, Oficio de Felipe Becerra, año 1628, caja 9495, fol. 912-913, 914, 995 y10491050; año 1631, caja 9498, fol. 692r.

${ }^{38}$ AHPL. Protocolos de Astorga, Oficio de Felipe Becerra, año 1633, caja 9500, fol. 1212-1216.

${ }^{39}$ AHPL. Protocolos de Astorga, Oficio de Felipe Becerra, año 1631, caja 9498. fol. 1118-1121.

${ }^{40}$ Algunos de los documentos donde Juan de Peñalosa aparece como Vicedeán de la Catedral de Astorga son: AHPL. Protocolos de Astorga, Oficio de Francisco de Balboa, año 1632, caja 9530, fol. 1017-1018,
}

anterior a abril de 1633, ya que a partir de este momento, el pintor desaparece de la documentación, pudiendo esto indicar que, habiendo caído enfermo, se hubiese retirado de la vida eclesiástica.

Pese a este ascenso social, y consecuentemente, dinerario, los problemas económicos del pintor le acompañaron también en el ocaso de su existencia. Por un Protocolo Notarial de 1632, hemos podido saber que, el Marqués de Astorga, Don Álvaro Pérez Osorio, prestó al canónigo mil cuatrocientos reales en moneda de vellón ${ }^{41}$, lo que demuestra además, las buenas relaciones que tuvo en vida, incluso con la nobleza. Este escrito es de gran importancia porque por primera vez en la documentación conocida sobre Juan de Peñalosa y Sandoval, se hace referencia a un familiar suyo: Gaspar de Peñalosa y Sandoval, Capitán de su Majestad en la cárcel de Córdoba, hermano del otorgante, y que estaba presente en la ciudad por esas fechas.

En este escrito también se nombran tres personajes muy cercanos a Peñalosa, sus criados, Santiago Colino, clérigo de menores y Catalina de Losada, y Francisco Álvarez mozo, hijo de Pedro Álvarez de la Torre, maestro mayor de las obras de la Catedral que había muerto en 1631.

Las siguientes referencias halladas entre los protocolos notariales de Astorga de las que disponemos para estudiar la biografía de Juan de Peñalosa son su testamento, y los consiguientes inventario de bienes y almoneda encontrados por Fernando Llamazares Rodríguez ${ }^{42}$. El primero de ellos, el testamento, ${ }^{43}$ va acompañado de

1026-1028 y 1183-1184.

41 AHPL. Protocolos de Astorga, Oficio de Felipe Becerra, Año 1632, Caja 9949. Fols. 1191-1192.

${ }^{4}$ Vid. F. LlamaZARES RODRÍGUEZ, «Juan de Peñalosa y Sandoval....» Op. Cit.

${ }^{43}$ El documento de testamento en sí, firmado por el propio Peñalosa se encuentra en: AHPL. Protocolos 
una serie de cartas que atestiguan la muerte del canónigo pintor la noche del 31 de mayo de 1633, a las nueve y media, siendo el cuerpo visto por el doctor Miguel López a las diez y media de esa misma noche, según el testimonio de otro escribano, llamado por el propio médico a testificar la muerte y tomar declaración de las personas que allí se encontraban ${ }^{44}$. Tales documentos atestiguan el fin de la peripecia vital de nuestro Peñalosa, pero nuestro objetivo es también reflejar el panorama de su producción artística y el significado que ésta pudo tener en los contextos culturales en los que nuestro clérigo pintor se desenvolvió.

Primera y cronológicamente hemos de centrarnos en las realizaciones artísticas que llevó a cabo en Córdoba. Conocemos algunos lienzos firmados que nos han permitido establecer comparaciones estilísticas con otras obras de Córdoba y Astorga y realizar atribuciones fundamentadas en caracteres formales, cromáticos y estilísticos. Llegados a este punto es necesario hacer notar que el estilo de Peñalosa no va a variar o evolucionar sustancialmente a lo largo de su carrera, si no más bien lo contrario, siendo las obras realizadas para la Catedral asturicense de un carácter, si cabe, retrógrado o arcaico, seguramente para adecuarse a la decoración de tipo flamenco del XVI que ya existía en el edificio y aproximándose, cada vez más, a los modelos pictóricos realizados por Céspedes, al estilo del renacimiento italiano, de al menos treinta años antes.

En la pintura de Peñalosa, sobre todo en la realizada a partir de su marcha a Astorga, se puede registrar un carácter casi

de Astorga, Oficio de Felipe Becerra, Año 1633, Caja 9500. Fols. 1212-1216. No obstante, pueden empezarse a leer los documentos precedentes a su testamento en los folios 1208 a 1211 del mismo legajo.

44 AHPL. Protocolos de Astorga, Oficio de Francisco Balboa, Año 1633, Caja 9531. Fol. 590. "arqueológico" que queda patente en el hecho de que el pintor admira más la antigüedad y la pintura realizada a la maniera de los pintores italianos del renacimiento, que los cambios formales modernos que se estaban produciendo en la pintura coetánea. Así, mientras él sigue realizando una pintura que imita la de su maestro Pablo de Céspedes y va involucionando cada vez más, los derroteros de la pintura en su época ya van avanzando hacia el claroscuro.

El lienzo conocido más antiguo de nuestro pintor se encuentra en Salamanca y representa un San Francisco Penitente, firmado y fechado: Ioanes d Peñalosa depingebat Cordubae. $1609^{45}$. También firmados y hoy conservados en el Museo de Bellas Artes de Córdoba, se encuentran la Asunción de la Virgen (1610), Santo Tomás de Aquino ante el Crucifijo, el Martirio de San Pedro de Verona (ambos hacían pareja y han sido fechados ca. 1610-1615) y la Virgen del Rosario con San Acisclo y Santa Victoria (ca. 1615-1620). Sin firmar, en este mismo Museo está la Virgen de la leche que durante mucho tiempo perteneció a los fondos del Museo del Prado y que ha sido recientemente devuelta a Córdoba.

Pérez Lozano atribuyó a Peñalosa un Crucificado que se encuentra en la Parroquia de San Andrés de Córdoba y dató su ejecución entre los años 1608 y 1610 por la gran similitud de estilo con el cuadro salmantino ${ }^{46}$. En la misma Parroquia cordobesa, también se encuentra una Imposición de la Casulla a San Ildefonso, identificada por

${ }^{45}$ E. MONTANER LÓPEZ, La pintura Barroca en Salamanca. Universidad de Salamanca. Salamanca, 1987, p. 159. M. PÉREZ LOZANO, «Aportaciones a la obra del pintor Juan de Peñalosa (Baena 1579-Astorga 1633)», en II Encuentros de Historia Local, Córdoba, 1991, pp. 413-421. F. Moreno CuAdro y J. M. PALENCIA CEREZO, San Juan de la Cruz y Córdoba. El convento de Santa Ana, Córdoba, 1989, p. 62.

${ }^{46}$ M. PÉREZ LOZANO, «Aportaciones...» Op. Cit, p. 415. 
Pérez Lozano a partir de los rasgos estilísticos, su correspondencia en el tratamiento iconográfico con otro lienzo que se encuentra en la Catedral de Astorga y por la firma, parcialmente borrada, en la que puede leerse: Peña... Fec ${ }^{47}$.

En otras ubicaciones cordobesas podemos encontrar otras obras, como en el Monasterio de San Jerónimo de Valparaíso, propiedad de los Marqueses del Mérito, una Última Cena, firmada y fechada en 1613 que, según la inscripción del marco, es copia de una anterior obra de Céspedes y en la Mezquita-Catedral de Córdoba, firmó una Santa Bárbara (c.a. 1618-1620), que podría ser, si aceptamos esta cronología, una de las últimas obras realizadas por el pintor antes de su marcha a Astorga ${ }^{48}$.

Además de estas, no queremos pasar sin mencionar una obra que atribuimos al catálogo pictórico de Peñalosa y a la que por no haber sido publicada con anterioridad, vamos a dedicar una atención especial. Se trata de un San Juan Bautista que se encuentra en la Capilla del Rosario de la Mezquita Catedral de Córdoba, que pensamos, el pintor realizaría hacia $1615 \mathrm{y}$, aunque no esté firmada ni documentada, responde a la mayoría de las características que definen la etapa cordobesa del pintor, compartiendo muchos rasgos con obras que ya hemos ido analizando.

Si estudiamos las particularidades y el conjunto podemos ver las notables similitudes entre esta y las obras documentadas tanto del pintor como de Céspedes. En esta obra están presentes detalles que pueden

-

${ }^{47}$ Ídem, p. 419-420.

48 De la mayoría de estas obras tenemos referencias a través del ya citado artículo de M. PÉREZ LOZA$\mathrm{NO}$, «Aportaciones...» y de su tesis doctoral, inédita: $E l$ Gongorismo y el Culteranismo en la pintura andaluza del Siglo de Oro". Para algunas de las obras que se encuentran en la Catedral de Córdoba, vid. M. A. RAYA RAYA, Catálogo de las Pinturas...Op. Cit, pp. 52-53. relacionarse claramente con las obras firmadas de Peñalosa, como por ejemplo el libro que porta el santo en los brazos que aparece decorado con dos broches, que son idénticos a otros que hemos visto en anteriores lienzos, como en el de San Francisco del Convento de las descalzas de Salamanca, obra que sí está firmada, o el Santo Tomás de Aquino ante el Crucifijo del Museo de Bellas Artes de Córdoba.

Además, de este detalle, también puede observarse que la forma de pintar el cuello, con la "V" invertida, también responde a obras que hemos ido viendo con anterioridad. El tipo de cara y cabeza del San Juan Bautista, además de en la forma del cuello y la postura, es prácticamente idéntico, aunque realizado de una manera más tosca, al del apóstol de la Asunción de la Virgen del Museo de Bellas Artes de Córdoba, aunque en éste lienzo, las sombras están mejor difuminadas y va suavizando el estilo. Esta figura, también guarda una relación muy estrecha con el San Andrés del Retablo de la Capilla de Santa Ana, obra atribuida a Pablo de Céspedes, en la que pensamos, también participaría Peñalosa en calidad de aprendiz o ayudante del racionero.

Otro aspecto que ha servido para la atribución es el hecho de que este San Juan porta una cruz con cinta en que puede leerse parte de la inscripción bíblica latina: "Ecce Agnus Dei, ecce Qui tollit peccatum mundi" (Juan, 1: 29). Idéntico motivo puede verse en el San Juan Bautista, más avanzado, del Retablo de Santa Teresa de la Catedral de Astorga, lienzo documentado del pintor, que trataremos más adelante y en otro San Juan presente en el lienzo central del Retablo de la Capilla de Santa Ana de Céspedes, que muy probablemente le sirvió de modelo.

Por último nos centraremos en la composición, la cual muy probablemente 
fue tomada de alguna estampa del siglo XVI. En una radiografía realizada a un San Juan Bautista de Tiziano que se encuentra en el Monasterio de El Escorial (Madrid), se ve una composición muy parecida a la del San Juan de Peñalosa. Seguramente Tiziano, en un principio se basó en esta supuesta estampa, aunque luego modificó su obra mostrando un aspecto que hace que a simple vista, ambas obras no puedan ser relacionadas. No obstante, se conocen copias de la primitiva obra de Tiziano, semejante a la cordobesa, aunque la figura de Peñalosa sólo se realizó de medio cuerpo.

Creemos que no estamos muy desorientados al atribuir esta obra a Juan de Peñalosa, aunque está claro que, comparada con las pinturas que realizó en Córdoba, ésta resulta de una factura más dura y seca, más cercana a las que realizaría en Astorga, como veremos a continuación.

Ya en esta ciudad, como dijimos, Peñalosa entrará rápidamente en contacto con el Obispo y será cabeza activa en el programa decorativo que elaboró para la Catedral. En estas obras, tuvo nuestro pintor una importancia clave y por lo que hemos podido extraer de la documentación que se encuentra en el Archivo Histórico Provincial de León, va mucho más allá de lo que hasta ahora se creía.

En primer lugar, Messía de Tovar encargó la realización de las puertas de la Sacristía de la Catedral a Lupercio Getino, en $1621^{49}$ y en 1622 la realización de la reja del coro, aunque no se concluiría hasta $1629^{50}$. En esta obra intervinieron escultores de bastante renombre en el círculo astorgano como Gregorio Español y Diego de Gamboa, que fueron, junto con Francisco

\footnotetext{
${ }^{49}$ AHPL. Protocolos de Astorga, Oficio de Marcos de Vega, año 1621, caja 9401, fol. 100-1103.

${ }^{50}$ M. A. GONZÁLEZ GARCÍA, «La reja del Coro de la Catedral de Astorga», Astorica, 4, 1986, pp. 167-206.
}

Ruíz, los que a partir de 1622, se encargaron de realizar el ensamblaje de otras de las grandes intervenciones del obispo en la Catedral, los Retablos de la Majestad, la Inmaculada y Santa Teresa, cuyos diseños y pinturas fueron realizados por Juan de Peñalosa y Sandoval. Además de estos proyectos, el prelado también encargó para el palacio episcopal el proyecto de un balcón y vista del cabildo en la plaza de la ciudad en $1626^{51}$.

Los contratos hallados en el Archivo Histórico Provincial de León entre el Obispo y su cabildo y los artistas que tenían que hacerse cargo de la construcción de las puertas de la Sacristía, el balcón y el retablo de la Inmaculada Concepción (diseño documentado de Juan de Peñalosa), van acompañados, como era habitual en la época por unas condiciones que normalmente, eran escritas por el propio tracista o diseñador.

Si se estudia el documento de condiciones de las puertas de la sacristía de la Catedral y la grafía de la escritura con la que está elaborado, es muy probable que quien hizo las condiciones de éstas en 1621, sea también quien escribió las del retablo. Esto supondría que el diseño de las puertas fue el primer trabajo que Peñalosa llevó a cabo para el obispo, siendo a partir de este momento cuando empezase a desempeñar una tarea que podríamos calificar de asesor artístico de las obras del obispo. Igual ocurre con el documento de condiciones para la realización de la vista y el balcón del cabildo en la plaza, en que las condiciones están elaboradas por la misma persona que realizó los anteriores documentos ${ }^{52}$.

También en 1621 podría fecharse una obra atribuida por Manuel Pérez Lozano a

\footnotetext{
51 AHPL. Protocolos de Astorga, Oficio de Luis Gaspar, año 1626, caja 9486, fol. 118-122.

52 Ibidem.
} 
Peñalosa $^{53}$. Se trata del Juicio Final que actualmente se encuentra en la caja de escaleras del Museo de la Catedral de Astorga. Es una obra que se inspira claramente en el Juicio Final que realizó Maarten de Vos para el Convento de San Agustín de Sevilla en 1570 y que actualmente se encuentra en el Museo de Bellas Artes de Sevilla, siendo igual, básicamente, la estructura de ambas obras aunque la de Vos es de mayor calidad, tanto en el dibujo y la composición, como en el color.

En esta obra, también puede verse relación con el Juicio Final que Francisco Pacheco concertó en 1610 con Hernando de Palma para que estuviese en el altar y entierro de éste en la Iglesia de Santa Isabel de Sevilla y que hoy día se encuentra en el Museo de Castres, tras ser arrancada de su retablo por orden del Mariscal Soult a principios del siglo XIX ${ }^{54}$.

Es muy probable que Peñalosa viese estas obras, ya que es posible que si no estancias largas, el pintor hiciese al menos visitas a Sevilla, donde podría haber tenido relación con el que fue un gran amigo y admirador de Pablo de Céspedes, Francisco Pacheco.

El Juicio Final, aunque no está firmado ni documentado, tiene mucha relación con la producción de Juan de Peñalosa en Córdoba y por este motivo ha sido datada en 1621, año en que Peñalosa llega a Astorga, dejando para posteriores estudios la resolución de la duda de si fue pintada en Córdoba y llevada a esta ciudad o si fue de las primeras obras que realizó allí.

En 1622 puede fecharse El Milagro o Exvoto a la Virgen de la Majestad, un cuadro que está en relación con la devoción del

\footnotetext{
${ }^{53}$ M. PÉREZ LOZANO, «Aportaciones...» Op. Cit, p. 413.

${ }^{54}$ E. VALDIVIESO Y J. M. SERRERA, Pintura sevillana del primer tercio del siglo XVII, Madrid, 1985, p. 79.
}

Obispo y que se encuentra en la Catedral Asturicense. El lienzo representa un milagro que tuvo lugar en Astorga en el año 1436, cuando según la tradición, la Virgen de la Majestad salvó a dos trabajadores de San Román, localidad cercana a Astorga y perteneciente a esta diócesis, que habían quedado atrapados en un pozo.

Aunque esta obra no está firmada, los rasgos estilísticos tan claros y su enorme parecido con otras obras de Juan de Peñalosa han llevado a que algunos autores hayan hecho esta atribución con la que nosotros estamos totalmente de acuerdo ${ }^{55}$.

Messía de Tovar, como ya sabemos por la cartela que se encuentra en el Retablo de la Inmaculada Concepción, encargó a Juan de Peñalosa, además de este Retablo, dos que se hicieron con anterioridad, el dedicado a la Virgen de la Majestad, y el de Santa Teresa de Jesús, a la que según parece tuvo oportunidad de conocer y de quien era gran devoto. ${ }^{56}$

El primer gran encargo para la Catedral de la diócesis es el Retablo de la Majestad (ca. 1622-1624). La autoría del diseño y las pinturas de éste no plantean duda alguna por la cartela que con anterioridad mencionamos, aunque sí pudiera plantearla la cronología. Sabemos por el libro de la Relación de las Fiestas que se celebraron en la ciudad de Astorga, el obispo y su cabildo que el propio Peñalosa escribió, que los retablos de Santa Teresa y la Majestad estaban ya con-

\footnotetext{
${ }^{55}$ M. PÉREZ LOZANO, «Aportaciones...», Op. Cit, p. 413; M. PÉrez LozAno, El Conceptismo..., Op. Cit., pp. 336-337. VELAdO GRAÑA, en la introducción a J. DE PEÑAlOSA Y SANDOVAL: La relación..., Op. Cit. p. XVI; M. ARIAS MARTíNEZ, «La fortuna de los grabados de Sadeler en el ámbito leonés. Algunos ejemplos de su seguimiento en escultura y pintura entre los siglos XVI y XVII», De arte: revista de historia del arte, no 1, León, 2002, p. 93.

${ }^{56}$ M. PÉrez LOZANO, «Aportaciones...», Op. Cit, p. 418; VELAdO GRAÑA, en la introducción a J. DE PEÑALOSA Y SANDOVAL, La relación..., Op. Cit.
} 
cluidos y colocados en 1626, cuando tuvieron lugar estas fiestas ${ }^{57}$.

Según Llamazares Rodríguez, la traza del retablo la realizó Lupercio Getino ${ }^{58}$, y el pago de todos los costes lo realizó Alonso Messía de Tovar, que quería reavivar el culto a la que ocuparía la zona central del retablo, la Virgen de la Majestad, una talla del siglo XII, a la que el obispo tenía gran devoción por haber obrado varios milagros.

Tres son las pinturas realizadas para este retablo por Peñalosa: un San Genadio, una Santa Teresa y la Imposición de la Casulla a San Ildefonso, que tiene prácticamente el mismo esquema que la obra pintada con el mismo tema para Córdoba en 1618 y en el que, se ha apuntado que podría estar representado el propio Messía de Tovar, en la figura de San Ildefonso ${ }^{59}$.

La presencia de San Genadio es especial ya que además de aquí, aparece representado en el libro De Vera et Falsa Gloria escrito por Messía de Tovar en 1624, año en el que, también situamos la fecha de conclusión del retablo. Aunque con pequeñas diferencias en la pose, ambas representaciones del santo están muy relacionadas, por lo que cabría pensar que la realización de ambas imágenes estaría muy cercana en el tiempo, coincidiendo además con el hecho de que Messía, por estas fechas, pudo rescatar los restos del santo y trasladarlos de nuevo a su diócesis.

De 1626 es el diseño de un balcón que diese a la plaza principal de la catedral desde el Palacio Episcopal, hoy desaparecido tras un incendio que tuvo lugar $1886^{60}$.

\footnotetext{
${ }^{57}$ J. DE PEÑAlOSA Y SANDOVAL, La relación..., Op. Cit., pp. 17-18.

${ }^{58}$ F. LlamaZares RoDRÍGUEZ, Astorga, León, 1979, p.37.

${ }^{59}$ M. PÉrez LOzAno, El Conceptismo..., Op. Cit., pp. 336-337.

${ }^{60}$ AHPL. Protocolos de Astorga, Oficio de Luis
}

En el documento de las condiciones de este diseño, que también pensamos fue redactado por Peñalosa, se explicitan hasta los más mínimos detalles, como que el balcón tenía que medir 56 pies de ancho, que tenía que contar con tres puertas-ventanas o que el conjunto al completo debía ser pintado con cal tanto al interior como al exterior.

Según el documento de contrato de la obra, sabemos que el encargado de realizarla fue Juan Díez, maestro de obras y carpintero, quien debería tenerla realizada para el día 15 de marzo de 1626.

Además de esto, junto con el contrato y las condiciones, en este mismo legajo se había conservado la planta que de la obra se realizó a mano y que debía ser tomada como patrón y que pudiera haber sido realizado por el propio Juan de Peñalosa.

Por estas fechas, parece ser que Peñalosa ya había adquirido un lugar importante en el ambiente asturicense como personaje culto y artista polifacético, pintor, diseñador y a partir de este momento, escritor o cronista, debido a que en 1626 y hasta 1629, se va a encargar de recoger las crónicas de unas fiestas en honor a la Inmaculada Concepción que se celebraron a expensas del obispo en la ciudad, siendo ésta su única obra en prosa conocida, llamada Relación de las fiestas que celebraron la ciudad de Astorga, el Obispo y su Cabildo, Marqués y su ciudad, en el voto y solemnidad de la Purísima Concepción de Nuestra Señora, dedicada a Don Pedro Messía de Tovar, hermano del obispo, por facilitar fondos para promover las empresas artísticas que se llevaron a cabo en la Catedral de Astorga.

Del Retablo de Santa Teresa, que estaba terminado ya en 1629 cuando Peñalosa había concluido la Relación de las Fiestas... ${ }^{61}$

\footnotetext{
Gaspar, año 1626, caja. 9486, fol. 118-122.

${ }^{61}$ J. DE PEÑAlOSA y SANDOVAL, La relación..., Op.
} 
y cuya ejecución nosotros situamos entre 1624 y 1626, sabemos que Peñalosa diseñó las trazas, pero no quién se encargó de su ensamblaje. En el banco, se sitúan los padres de la iglesia a los lados y en el centro, una imagen de Cristo de perfil en la puerta del Sagrario. Esta imagen de Cristo guarda una estrecha relación con la que para la puerta del Sagrario en el Retablo de la Capilla de Santa Ana hizo Céspedes en la Catedral de Córdoba.

En el cuerpo, la calle central se ocupa por una gran hornacina de medio punto donde se sitúa una imagen escultórica de santa Teresa como doctora y acompañada por el Espíritu Santo. La imagen, bastante deteriorada, está flanqueada, en la calles laterales, por cuatro imágenes que representan Santas (Escolástica, Catalina de Siena, Paula y Clara) cuya vida eclesiástica había sido muy importante, ya sea por haber fundado conventos, por haber sido nombradas doctoras de la iglesia o por haber apoyado y seguido a los hombres más importantes del cristianismo.

La obra más interesante de este retablo, y una de las más logradas de toda la producción pictórica de Peñalosa, es la Imposición del Collar a Santa Teresa, que se encuentra en el ático de este retablo. En este lienzo se representa una escena tomada de la autobiografía de Santa Teresa, El Libro de la Vida, en el que la Santa relata

Cit., pp. 17-18:

...Al lado derecho, en la capilla colateral, está otro retablo, si no en cantidad, en calidad no menos excelente, por la arquitectura y traza de él como por la pintura que lo hace raro, en cuyo nicho principal incluye una milagrosa imagen que se intitula de la Majestad, de las más antiguas de Espa$\tilde{n} a$, por quien hoy la Iglesia goza rentas y lugares, mercedes hechas de los antiguos Reyes de León y de Castilla, con quien esta Señora obró prodigiosos milagros. Este pues retablo y trono costoso le erigió el Sr. Obispo a su costa, por estar antes en tabernáculo pobre y poco decente. $Y$, no contento con esto Su Señoría, levantó otro no menos costoso y rico a la Santa Madre Teresa de Jesús, de quien es tan particular devoto... cómo la propia Virgen le impuso el collar el 15 de agosto de $1561^{62}$.

Peñalosa representa en el lienzo de manera bastante fiel lo relatado, pero al igual que harán otros pintores, la Santa no vestirá de blanco, si no con el hábito carmelitano, posiblemente para hacerla reconocible a los fieles. La escena es simple, aparecen la Virgen y San José imponiendo el collar a Santa Teresa, que mira a María, quedando San José, en un segundo plano tras la Santa. El collar, bastante suntuoso y terminado en una cruz colgante, recuerda al que podíamos ver en el lienzo de Santo Tomás de Aquino del Museo de Bellas Artes de Córdoba y que puede estar en relación con las obras que el pintor habría visto muy de cerca, por el trabajo de platero de Alonso de Peñalosa.

De fondo, un celaje amarillento con nubes grises, característico de los rompimientos de Gloria de Peñalosa, se completa por una serie de querubines en la parte superior y en la izquierda y un gran ángel en la esquina superior derecha, que es una de las figuras más logradas de toda la producción de este pintor, que por su elegante y complicada postura, está bastante conseguida. Su elegante y complicada postura nos hace pensar que está tomada de algún grabado o estampa que el canónigo poseía y que todavía no hemos podido identificar.

Flanqueando esta imagen, a la izquierda San Juan Bautista, en una imagen muy relacionada con el San Juan Bautista realizado por Céspedes para la obra central del Retablo de la Capilla de Santa Ana de Céspedes y a la derecha, San Juan Evangelista.

La última obra del pintor que se ha conservado en la Catedral es el Retablo de la

${ }^{62}$ SANTA TERESA DE JESÚs, El libro de la Vida. (2 ${ }^{-}$ Edición), Madrid, 1991. 
Inmaculada Concepción. Varios son los datos que tenemos para fechar con seguridad esta obra en un momento posterior a 1627. En primer lugar, existe un documento por el cual Juan de Peñalosa redacta las condiciones para hacer un retablo ${ }^{63}$ para la Inmaculada Concepción en la Catedral de Astorga que están anexas al documento de realización del mismo, que debía ser ensamblado por Francisco Ruiz, maestro natural de la ciudad de León del que no tenemos más datos $^{64}$. En segundo lugar, y como ya hemos referido, en la Relación de las Fiestas ${ }^{65}$ se menciona la existencia de los dos retablos de los que ya hemos hablado (La Majestad y Santa Teresa) y de este no menciona nada porque aún no estaba hecho. La fecha de culminación del retablo es 1630, cuando Juan de Meaza concluyó el dorado del mismo ${ }^{66}$.

Messía de Tovar mandó realizar la imagen a Gregorio Fernández y para poder instalarla con el honor que merecía, encargó el diseño de un retablo de madera de nogal al que había sido el autor de las más importantes obras que había emprendido en la Catedral, Juan de Peñalosa y Sandoval.

El Canónigo sometería su proyecto a Don Pedro Álvarez de la Torre, maestro mayor de las obras de la Catedral y la realización del ensamblaje la llevaría a cabo Francisco Ruiz, que debía tener asentado el retablo en unos ocho meses.

Si comparamos las condiciones de las trazas y el retablo que hoy se nos ha conservado, podemos comprobar cómo Francisco Ruiz siguió perfectamente las pautas

\footnotetext{
${ }^{63}$ AHPL. Protocolos de Astorga, Oficio de Pedro Salazar, año 1627, caja 9417, fol. 45-50.

${ }^{64}$ Vid. F. LLAMAZARES RODRÍGUEZ: El retablo..., Op. Cit, p. 174.

${ }^{65}$ J. DE PEÑAlOSA Y SANDOVAL, Relación de las Fiestas..., Op. Cit, pp. 17-18.

${ }^{66}$ B. VELADO GRAÑA, Introducción a la Relación de las Fiestas..., Op. Cit, p. XVI.
}

apuntadas por nuestro canónigo y el aspecto final del retablo responde al diseño realizado por Peñalosa, teniendo bastante relación, iconográfica y estilística con el Retablo de Santa Ana obra de Céspedes y el de la Capilla de San Pablo, posible atribución al racionero, que se encuentran en la Catedral de Córdoba.

Además de la talla de Gregorio Fernández, el retablo está ornamentado por pinturas realizadas por Peñalosa, inspiradas en la vida de la Virgen. En los laterales, dos pequeños lienzos que representan dos escenas del Protoevangelio de Santiago en los Evangelios Apócrifos de Navidad, a la derecha, la Anunciación del Ángel a Santa y a la izquierda, la Anunciación del Ángel a San Joaquín. Esta última iconografía es usada también en el registro lateral izquierdo del Retablo de Santa Ana de Céspedes, y ambas comparten similitudes compositivas extremas, lo que relaciona las pinturas de ambos maestros.

Sobre los lienzos que flanquean la imagen de la Inmaculada, que son paisajes sin figuras, hizo un estudio Velado Graña en la introducción a la Relación de las Fiestas... de Peñalosa, interpretando cada uno de los lienzos con los atributos de la Inmaculada y sus metáforas tomadas del Cantar de los Cantares y de las Letanías a la Virgen $^{67}$.

En el ático, se encuentra el lienzo de El Abrazo en la Puerta Dorada, situado entre cuatro columnas, y los escudos del Obispo Alonso Messía de Tovar, muy devoto del dogma Inmaculista y donante del retablo. El lienzo en sí, en cuanto a composición y colorido es bastante arcaizante, más propio del siglo XVI tanto en el tratamiento de los paños como en la composición simétrica y el colorido, bastante llamativo y luminoso, y aunque Céspedes en el Retablo de Santa

\footnotetext{
${ }^{67}$ Idem, p. XVII.
} 
Ana cordobés, también usó esta iconografía en el banco, compositiva y estilísticamente estas obras no tienen semejanza alguna, no teniéndola tampoco con las pinturas que ocupan el banco del propio retablo. Esto pudiera deberse a que la gran obra central tuviera que adecuarse a las directrices de Messía de Tovar, mientras que en las del banco, más relacionadas con la pintura cespediana, hubiese tenido Peñalosa más libertad artística, realizando unas obras cercanas a las de su maestro.

Sobre los santos, un ángel, en un escorzo bastante valiente, tomado con seguridad de algún grabado procedente de la escuela veneciana, une a la pareja, como símbolo de que es el propio Dios quien protege el matrimonio y la concepción. De fondo unos personajes, que parecen pastores y que están representados como ajenos a la escena, justo delante de las puertas de la ciudad, que como su nombre indica, apa recen representadas de color dorado y como un arco de medio punto con casetones al más puro estilo clásico.

No conocemos más obras de Peñalosa, quien probablemente, tras ser nombrado Vicedeán en 1632, cayó en una enfermedad que le apartó tanto de la carrera eclesiástica como de la pintura. En su testamento aparecen nombrados varios enseres de pinturas y unas cuantas obras que estaban en su casa en el momento de su muerte y que hasta hoy no hemos podido identificar.

Murió el 31 de mayo de 1633, legando su herencia a su único familiar conocido, su hermano Gaspar de Peñalosa, dejando tras de sí, pleitos, deudas, una biblioteca propia de un hombre cultivado y una serie de incógnitas que aún hoy, no hemos sido capaces de despejar, ya que su memoria desapareció hasta que fue rescatada por Palomino y los historiadores que siguiéndole, se encargaron de buscar e identificar al más cercano seguidor de Céspedes documentado $^{68}$.
-

${ }^{68}$ Sobre el testamento e inventario de bienes de Juan de Peñalosa Vid. F. LlamaZares RodríGUez, «Juan de Peñalosa...», Op. Cit.

Para ver el testamento de Juan de Peñalosa: AHPL. Protocolos de Astorga, Oficio de Felipe Becerra, año 1633, caja 9500, fol. 1212-1216.

El Inventario de los bienes que dejó en su casa a su muerte: Idem, fol. 1208-1211.

AHPL. Protocolos de Astorga, Oficio de Francisco Balboa, Año 1633, Caja 9531. Fol. 590.

Para ver la Almoneda: AHPL. Protocolos de Astorga, Oficio de Felipe Becerra, año 1633, caja 9500 B, fol. 1312-1321. 


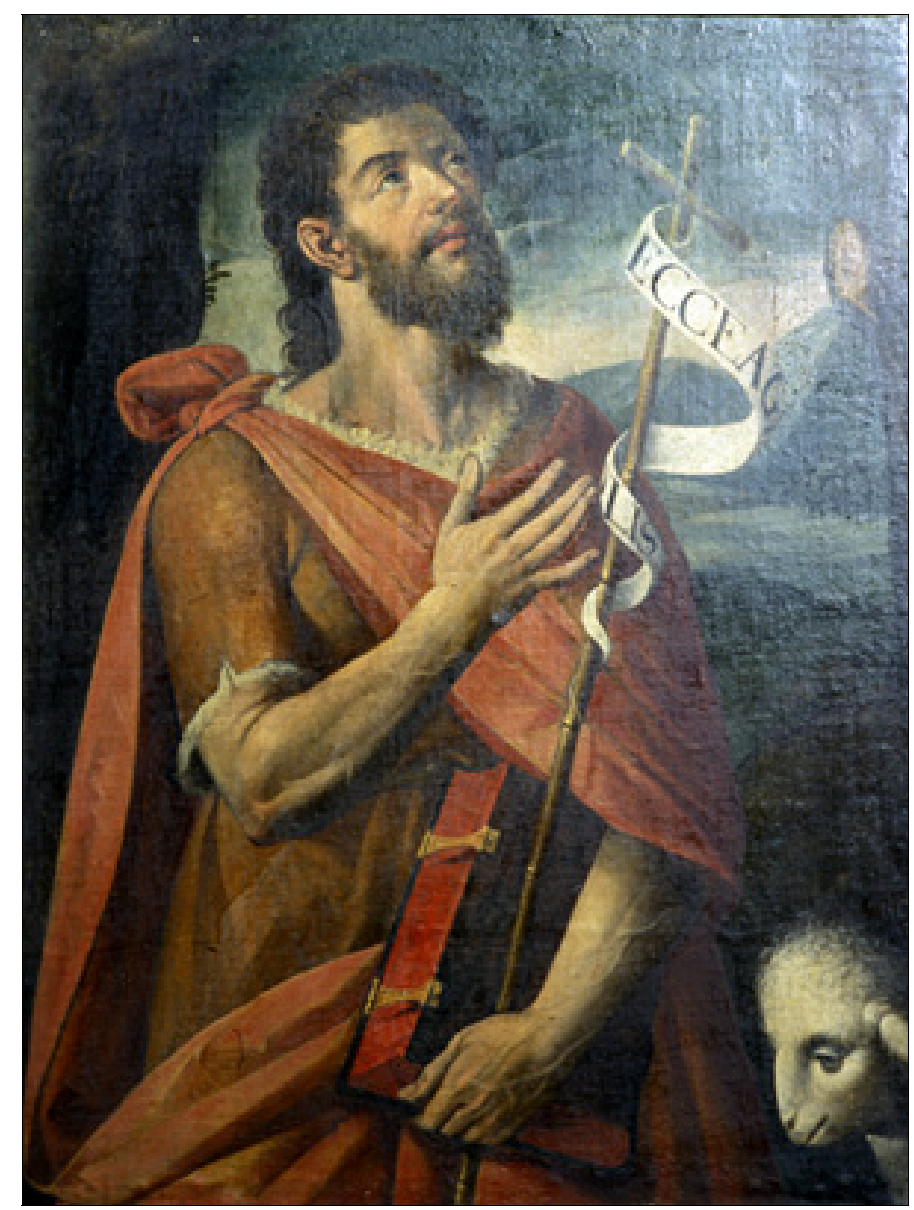

- Lám. 1. San Juan Bautista. (ca. 1615). Capilla del Rosario de la Mezquita Catedral de Córdoba.
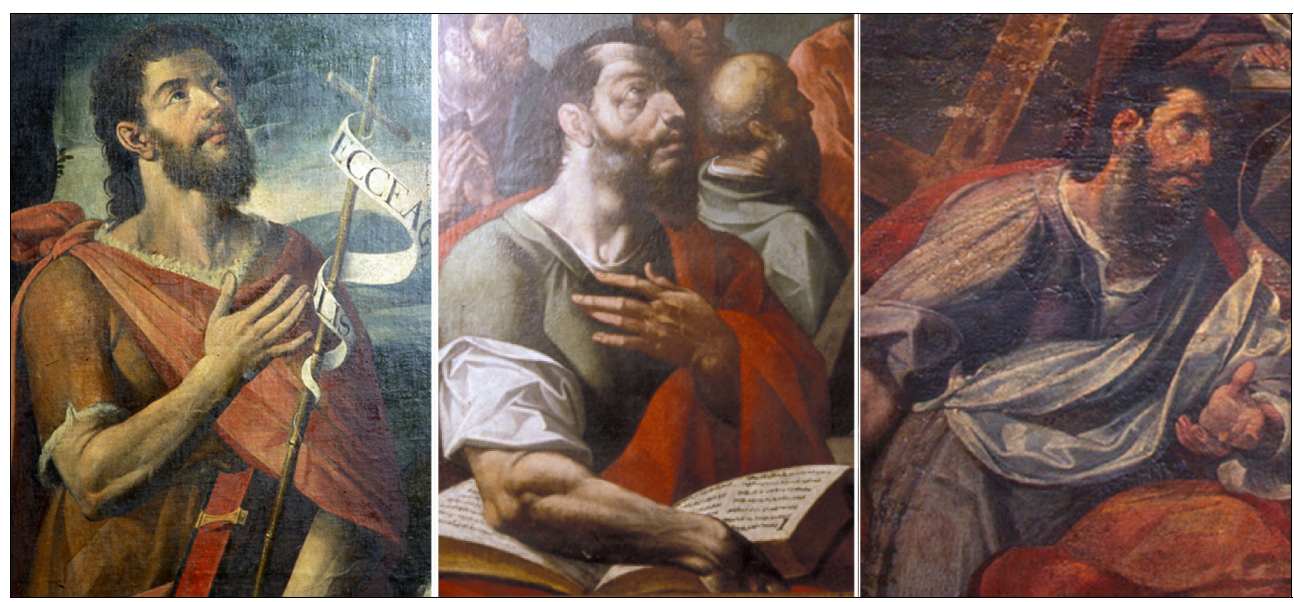

- Lám. 2. Detalle de San Juan Bautista, atribuido a Peñalosa (ca. 1615, Mezquita Catedral de Córdoba) detalle de personaje en la Asunción de la Virgen de Juan de Peñalosa (Museo de Bellas Artes de Córdoba) y Detalle del San Andrés del Retablo de la Capilla de Santa Ana de Pablo de Céspedes (ca. 1595, Mezquita Catedral de Córdoba). 

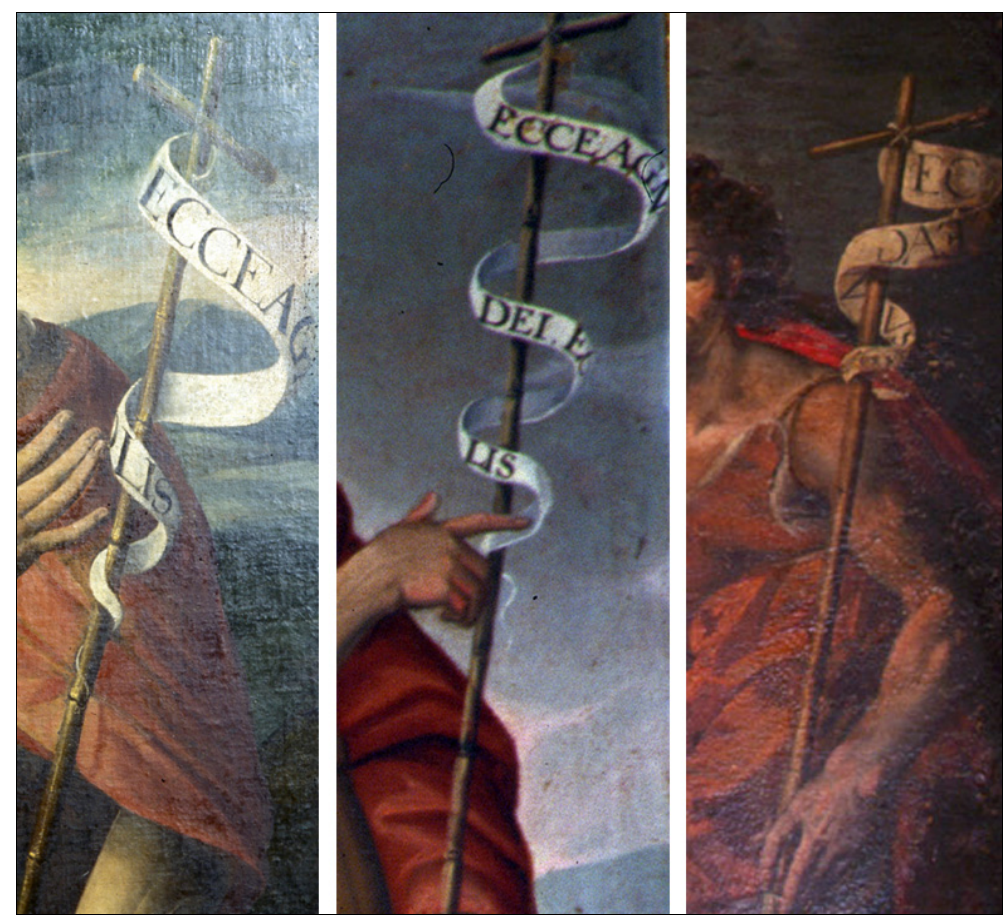

- Lám. 3. Detalle de San Juan Bautista, atribuido a Peñalosa (ca. 1615, Mezquita Catedral de Córdoba), detalle de San Juan Bautista de Juan de Peñalosa (Retablo de Santa Teresa de la Catedral de Astorga) y Detalle del San Juan del lienzo central del Retablo de la Capilla de Santa Ana de Pablo de Céspedes (ca. 1595, Mezquita Catedral de Córdoba).

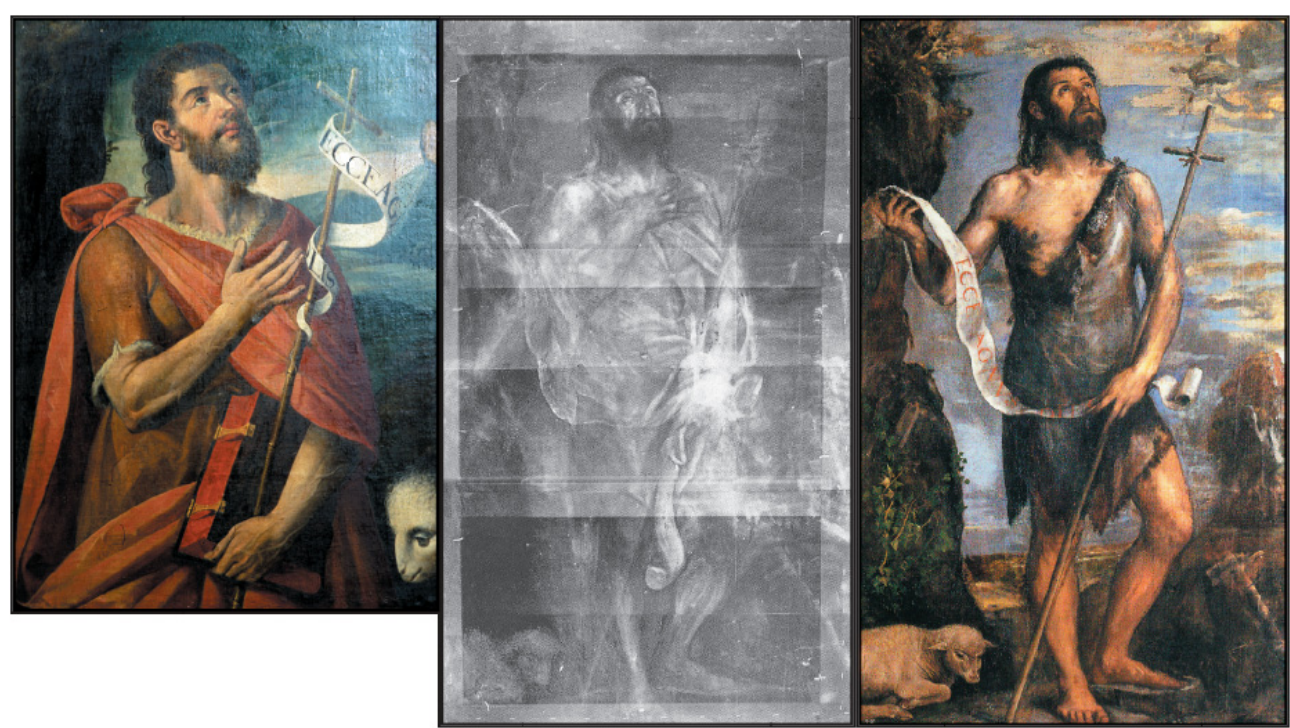

- Lám. 4. San Juan Bautista atribuido a Juan de Peñalosa (ca. 1615, Capilla del Rosario de la Catedral de Córdoba) y San Juan Bautista de Tiziano (Monasterio de El Escorial, Madrid), Radiografía y obra acabada. 

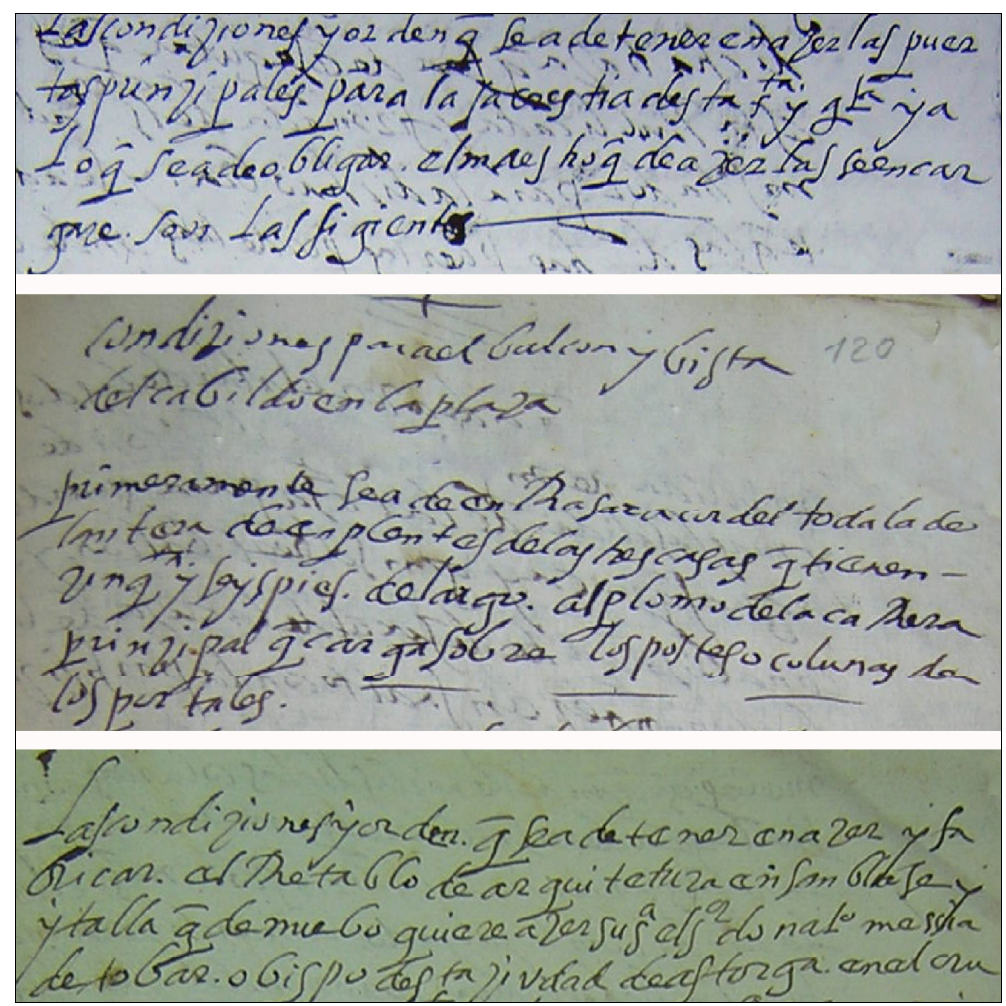

- Lám. 5. Detalles de documentos. De arriba a abajo: Condiciones para realizar las puertas de la Sacris-tía Catedral de Astorga, 1621; Condiciones para realizar el balcón y la vista del Cabildo de Astorga, 1626; Condiciones de la Arquitectura del Retablo de la Majestad de la Catedral de Astorga, 1627 (Archivo Histórico Provincial de León).
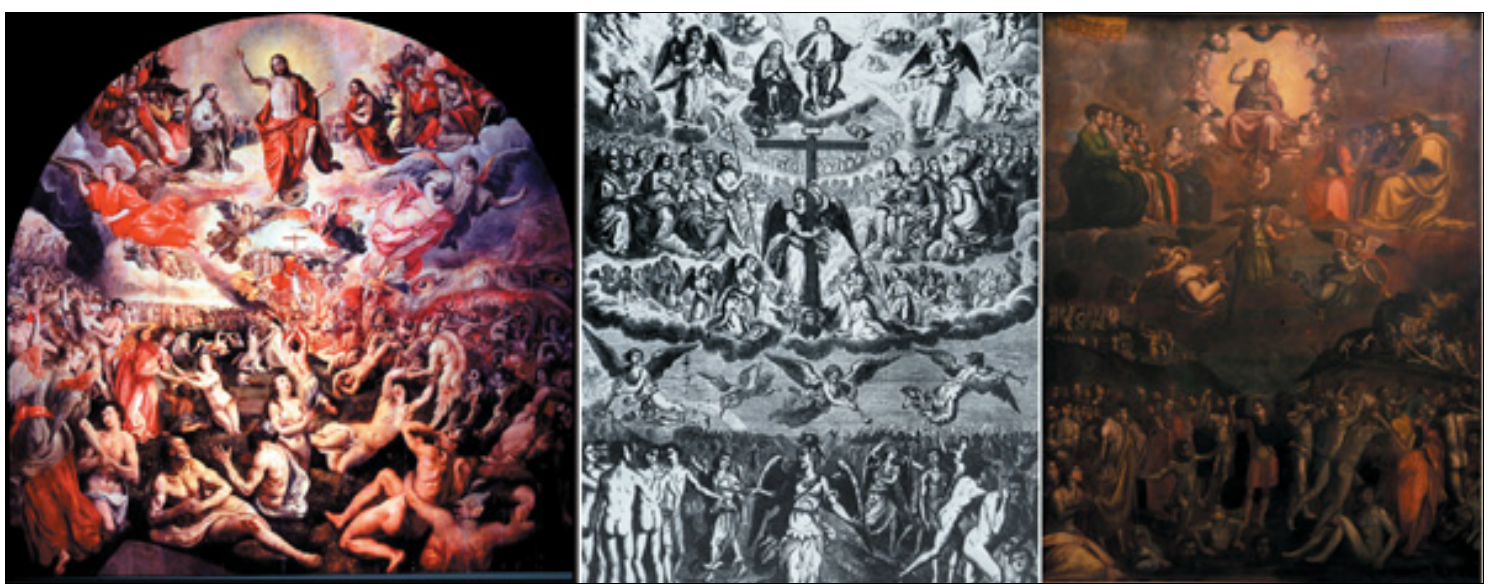

- Lám. 6. De izquierda a derecha: Juicio Final de Maarten de Vos (Convento de San Agustín de Sevilla), 1570. Grabado del Juicio Final de Francisco Pacheco (Colección Particular), 1610. Juicio Final de Juan de Peñalosa (Museo de la Catedral de Astorga), 1621. 